\title{
Effect of Feeding by Spirulina platensis and Kareish Cheese on Liver and Kidney Damage Induced by Lead Toxicity in Rats
}

\author{
Ayat E. Rizk ${ }^{* *}$ and A.B. El-Sayed ${ }^{2}$ \\ ${ }^{1}$ Department of Special Food and Nutrition, Food Technology Research Institute, Agricultural Research Center, Giza, Egypt \\ ${ }^{2}$ Fertilization Technology Department, Algal Biotechnology Unit, National Research Centre, Egypt
}

Received: $16 / 1 / 2018$

\begin{abstract}
Lead is considered a potential hazard for human and animal health. The present study was performed to evaluate chemical composition and mineral content of Spirulina platensis and Kareish cheese replace on hepatic and renal damage induced by chronic lead toxicity in Rats. Thirty adult female rats were randomly divided into five main groups (6 per each group). The G1 was kept as control (untreated group), G2 is lead intoxicated rats ( $2 \mathrm{~g} / \mathrm{L}$ lead acetate in drinking water), G3 rats fed on Spirulina ( $0.3 \%$ ) of diet plus lead acetate ( $2 \mathrm{~g} / \mathrm{L}$ water), G4 rats fed on Kareish cheese plus $2 \mathrm{~g} / \mathrm{L}$ lead acetate in drinking water and G5 rats fed on both Kareish cheese with Spirulina (0.3\%) plus 2 g/L water lead acetate. Kareish cheese has high nutritive value due to its high content of protein, ash, minerals (calcium, phosphorous) and vitamins. Also Spirulina platensis have nutrition value of protein, fiber, fat and minerals. Results showed that lead acetate increased the activities of AST, ALT, urea and creatinine, and decreased the contents of glutathione in liver compared to control. Also, revealed marked elevation in liver function markers and toxic renal metabolites in lead intoxicated rats as well as severe hepatic and renal alterations with increased lead tissue content in these organs. The sole replace of Spirulina and kareish or their combination were markedly improved both hepatic and renal functions, reduced their lead content and markedly ameliorated the hepatic and renal pathology induced by lead intoxication.
\end{abstract}

Keywords: Lead, Spirulina platensis, kareish cheese, liver, kidney, rats

\section{INTRODUCTION}

Lead $(\mathrm{Pb})$ toxicity is the most common form of heavy metal intoxication. It is well documented as one of the most dangerous and insidious poisons (ElNeweshy and El-Sayed, 2011). Lead toxicity has been recognized as a major environmental health hazard worldwide affecting both humans and animal all ages especially young children in humans for a long time (Lalith Kumar and Muralidhara, 2014). There are evidences, which show that lead is a toxic agent with multiple target organs such as hematopoietic system, immune system, kidneys, liver and nervous system. Lead does not have any beneficial effects to human, and its presence by high concentrations produce very undesirable toxic consequences to humans affecting all the body organs (Ibrahim et al., 2012). Lead is absorbed through digestive and respiratory tracts, and skin. After absorption into the blood, $99 \%$ of lead is bound to erythrocytes and the remaining of $1 \%$ stay in plasma to be carried to other tissues. Serum lead half-life is around 25 days (Kadhim et al., 2016). Liver and kidney are the major target organs of $\mathrm{Pb}$, this element is highly dangerous to hepatic and renal function (Yuan et al., 2014). Lead may be rapidly absorbed and reached considerable amount in the blood (Sharma et al., 2010) suggested that this element is strongly bound to macromolecules in the intracellular compartment because $\mathrm{Pb}$ binding proteins have been isolated from the kidney, liver, blood and brain explained the high concentration of $\mathrm{Pb}$ in tissue of kidney. The toxicity of many heavy metals is due to their ability to cause tissues oxidative damage. Damage includes enhanced lipid peroxidation, DNA damage and the oxidation of protein sulfhydral groups (El-Sokkary et al., 2005). Spirulina platensis or blue green algae are popularly used as a nutritional supplement as well as in therapeutic applications. Spirulina contains proteins, lipids, carbohydrate some vital minerals, essential fatty acids vitamins and a pigmented protein C-phycocyanin (Hemalatha et al., 2012). Spirulina contains antioxidants such as $\beta$-carotene and zeaxanthin. Spirulina may increase the production of immunostimulatory and immuno-modulator chemicals known as interferon and interleukins. Simultaneous administration of Spirulina and reduces levels of lipid peroxidation products. Spirulina has a significant effect on scavenging free radicals, thereby protecting the organs from damage caused by the exposure to lead (Rahman et al., 2012). Kareish cheese is one of the most popular cheese varieties consumed in Egypt especially in countryside owing to its high protein, low fat and reasonable price. It is an acid cheese made from skimmed cow's and buffalo's milk. Increased demand has led to the commercial production of Kareish cheese which, under such conditions, is frequently made from pasteurized and/or homogenized milk or reconstituted milk using Lactobacillus delbrueckii ssp. bulgaricus as starter and usually with rennet rather than acid as coagulant (Todaro et al., 2013). Lactic acid bacteria (LAB) are the basic in dairy fermented products such as yoghurt and Kareish cheese. In recent, LAB has drawn attention for their efficiency to secrete extracellularpolysaccharides (EPS). Worth mentioning, EPS include produced by LAB have various functional roles in human or animal health including immunomodulatory properties, antiviral activity, antioxidant activity and antihypertensive activity cholesterol-lowering activity. In addition, its properties of anti-tumor, anti-ulcer interests, at the same time, it has benefits as prebiotics (Abou Ayana and Ibrahim, 2015). This investigation 
aimed to study the effect of feeding female rats on kariesh cheese and Spirulina platensis to protect liver and kidney function from toxicity of lead acetate.

\section{MATERIALS AND METHODS}

Kareish cheese was obtained from Faculty of Agriculture, Cairo University. Spirulina platensis blue alga was obtained from Algal Biotechnology Unit National Research Centre, Giza, Egypt.

Sugar, corn oil from local market, salt mixture, vitamins mixture and Casein (protein $\geq 85 \%$ ) cellules and choline chloride were purchased from El-Gomhoria Company, Lead acetate was obtained from Sigma Chemical Company, Kits were used for determination of ALT, AST, ALP, creatinine, urea, MDA, SOD, Catalase, GSPx and GSH were purchased from Biodiagnostic Company, Cairo-Egypt.

Animals: Thirty adult Sprague-Dawley females (about $145 \mathrm{~g}$ ) in the animal house of the Ophthalmology Research Institute, Giza, Egypt, were used in the present study. The rats were kept under normal healthy laboratory condition; temperature was adjusted at
$25 \pm 2^{\circ} \mathrm{C}$ and 12 hour light-dark. Animals were adapted on free access of water, and fed for one week on basal diet before the initiation standard of the experimental according to Reeves et al. (1993) and modification the protein ratio Barltrop and Khoo (1975) to $20 \%$ in diet.

\section{Experimental design}

Five groups each of six female rats were housed in wire cages in a room temperature maintained at $25 \pm$ $2 \mathrm{C}^{\mathrm{o}}$ and kept under normal healthy conditions for 60 days. All rats and food consumption weight every week for determination the body weight gain. Rats of first group (G1) kept as negative control (normal control) fed on basal diet and drink tap water. Rats of group (G2) were used as positive control, fed on basal diet and drink water containing $2 \mathrm{~g} / \mathrm{L}$ lead acetate. Rats of (G3) fed on Spirulina $0.3 \%$ of diet plus lead acetate $(2 \mathrm{~g} / \mathrm{L}$ water). Rates of (G4) fed on Kareish cheese as protein $20 \%$ of diet and drink water which containing $2 \mathrm{~g} / \mathrm{L}$ lead acetate. Rats of the (G5) fed on mixture of $(31.1 \%)$ Kareish cheese $(20 \%$ protein of diet) with Spirulina $(0.3 \%$ of diet $)$ and drink water containing $2 \mathrm{~g} / \mathrm{L}$ lead acetate.

Table (1): Composition of the experimental diets (\%)

\begin{tabular}{lccccc}
\hline Ingredients & G1 & G2* & G3* & G4* $^{*}$ & G5* $^{*}$ \\
\hline Casein (Protein ) & 23.53 & 23.53 & 23.53 & -- & -- \\
Sugar & 10 & 10 & 10 & 10 & 10 \\
Corn oil & 10 & 10 & 10 & 10 & 10 \\
Salt Mix & 4 & 4 & 1 & 4 & 4 \\
Vitamin mix & 1 & 1 & 0.2 & 0.2 & 1 \\
Choline chloride & 0.2 & 0.2 & 5 & 5 & 0.2 \\
Cellules & 5 & 5 & --3 & -- & 5 \\
Spirulina & -- & -- & 45.97 & 31.1 & 0.3 \\
Kareish cheese & -- & 46.27 & & 31.1 \\
Corn starch & 46.27 & & & 38.4 \\
\hline
\end{tabular}

* Drinking water containing lead acetate $(2 \mathrm{~g} / \mathrm{L})$

G1 (normal control), (G2) positive + drink water containing $2 \mathrm{~g} / \mathrm{L}$ lead acetate. Rats of (G3) fed on Spirulina $0.3 \%$ of diet + lead acetate $2 \mathrm{~g} / \mathrm{L}$ water, (G4) rats fed on Kareish cheese $+2 \mathrm{~g} / \mathrm{L}$ lead acetate. Rats of the (G5) fed on Kareish cheese and Spirulina $+2 \mathrm{~g} / \mathrm{L}$ lead acetate

\section{Methods:}

Chemical analysis: Protein, fat, carbohydrates, moisture and ash content were determined according to AOAC (2000). Minerals were measured in the ash using atomic absorption, Unicam 929 (AOAC, 1981).

Growth of rats\%: The gain in the body weights was calculated by the following equation $=$ final weightinitial weight/initial weight.

Biochemical assay: At the end of the experimental period, blood samples were collected from the animals from the eye plexuses on ice. Each sample was collected into both heparinized tubes to obtain the plasma and put in a dry clean centrifuge glass tube to prepare serum. Blood was left for $15 \mathrm{~min}$ at room temperature, then the tubes were centrifuged for $15 \mathrm{~min}$ at $3000 \mathrm{rpm}$ and the clear supernatant serum was kept frozen at $-20^{\circ} \mathrm{C}$ until the analysis. Liver function: Alanine amino transferase (ALT) and Aspartate amino transferase (AST) activities were assayed by the method of Bergmeyer and Harder
(1986). Alkaline phosphatase (ALP) activity was measured at $405 \mathrm{~nm}$ by the formation of paranitrophenol from para-nitrophenyl phosphate as a substrate using the method of Varley et al. (1980). Kidney function: (Creatinine) was measured using the method of Henry (1974). Urea was measured using the method of Fawcett and Scott (1960). The activity of lipid peroxidation level (Malondialdehyde, MDA) was determined in serum by the colorimetric method described by Meltzer et al. (1997). Superoxide dismutase (SOD), catalase (CAT), glutathione peroxides (GSPx) and glutathione reduced (GSH) were measured calorimetrically in erythrocyte according to the methods of Nishikimi et al. (1972), Aebi (1984), Rotruck et al. (1973) and Ellman (1959), respectively.

Statistical analysis: All data were expresses as mean \pm stander error. The obtained results were subjected to statistical analysis using the standard analysis of variance as outlined by Snedecor and Cochran (1980). 


\section{RESULTS AND DISCUSSION}

Chemical composition of Kareich cheese and Spurilina plantesis:

Table (2) showed the chemical composition of kareich cheese and Spirulina plantesis. The results showed the protein, lipid, carbohydrate, fiber, moisture and ash contents were 16.5, 1.2, 5.0, 0, 74.3 and 3.0\%, respectively of Kareish cheese while it amounted in 50.6, 6.5, 20, 5.4, 7.1 and 10.4 of Spirulina platensis, respectively. The data (Table 2) revealed that the Kareish cheese rich in $\mathrm{P}(450 \mathrm{mg} / 100 \mathrm{~g}), \mathrm{Ca}(565$ $\mathrm{mg} / 100 \mathrm{~g})$ and $\mathrm{Mg}(8 \mathrm{mg} / 100 \mathrm{~g})$ while was about 5.11, 2.93 and 7.7 fold as that of Spirulina. Meanwhile, Spirulina characterized with high amounts of Fe (16.2 $\mathrm{mg} / 100 \mathrm{~g}), \mathrm{K}(125 \mathrm{mg} / 100 \mathrm{~g})$ and Se $(2.5 \mathrm{~g} / 100 \mathrm{~g})$ which was about 231.4, 1.2 and 3.6 fold as that of Karish cheese. The presence of $\mathrm{Zn}$ decrease of toxic effect of pb as mentioned by (Hassan et al., 2015). Calcium (Ca) plays a central role in nerve transmission and $\mathrm{Pb}$ has been postulated to act at synaptic sites by increasing the Ca flux (Silbergeld and Adler, 1978), the availability of $\mathrm{Ca}$ with changes in the $\mathrm{Pb}-\mathrm{Ca}$ interaction must influence this effect.

Table (2): Chemical composition (g/100g) and Minerals of kareich cheese and Spirulina plantesis

Chemical
composition Kareish cheese Spirulina platensis

\begin{tabular}{lcc}
\hline Protein & $16.5^{\mathrm{b}} \pm 0.93$ & $50.6^{\mathrm{a}} \pm 1.06$ \\
Lipid & $1.2^{\mathrm{b}} \pm 0.16$ & $6.5^{\mathrm{a}} \pm 0.21$ \\
carbohydrate & $5.0^{\mathrm{b}} \pm 0.19$ & $20^{\mathrm{a}} \pm 0.35$ \\
Fiber & $0.0 \pm 0.0$ & $5.4^{\mathrm{a}} \pm 0.24$ \\
Moisture & $74.3^{\mathrm{a}} \pm 1.45$ & $7.1^{\mathrm{b}} \pm 0.13$ \\
Ash & $3.0^{\mathrm{b}} \pm 0.13$ & $10.4^{\mathrm{a}} \pm 0.15$ \\
P (mg/100g) & 450 & 88 \\
Ca (mg/100g) & 565 & 193 \\
Zn (mg/100g) & 3.4 & 2.2 \\
Mg (mg/100g) & 8 & 1.1 \\
Fe (mg/100g) & 0.07 & 16.2 \\
K (mg/100g) & 104 & 2.5 \\
Se (mg/100g) & 0.7 & 125 \\
\hline (me & & \\
\hline
\end{tabular}

Means, within the same row, followed by the same letter are not significantly different at $\mathrm{P}<0.05$.

These effects were attributed to increase formation of insoluble $\mathrm{Pb}$ phosphate in renal cells following mitochondrial breakdown although it might have been attributed to changes in tubular reabsorption in the kidney. These effects on the kidney are analogous to those found by Kostial et al. (1974). Selenium content of Spirulina induced elevation of selenium containing enzymes as GSH peroxidase proteins thus modulating the toxic effects of heavy metals .On the other hand, Kareish contained various nutritive minerals including iron, calcium, zinc, selenium (Todaro et al., 2013).

Effect of kareish cheese, Spirulina plantesis and their mixtures on the body weight gain and relative weights of organs in experimental female rats induced with lead acetate

The effect of inducing lead acetate for 60 successive days period with kareich cheese, Spurilina plantesis and their mixtures on body weight gain of rats and relative weight of organs, had been summarized in Table (3). Data showed the initial body weights (143.3 $144 \mathrm{~g})$ which did not significantly differ among the groups. At the end of experiment, (G2) the positive control resulted in lowest significant increase (14.49\%) in body weight gain comparing negative control group $(37.96 \%)$. Meanwhile, the groups the body weights that gain of fed kareish cheese, Spirulina plantesis and their mixtures with lead acetate increased by $29.26,31.80$ and $33.12 \%$, respectively. On contrary, there were non significant differences found in liver and kidney relative weight of rats except in group G2 (Table 3). Djebli et al. (2004) suggested that the reduced growth was due to reduced food consumption via lead effects on the satiety set-up. Spirulina group (G3) succeeded to induce an improvement in body weight compared to positive control group (G2). El-Tantawy (2016) mentioned that improvement of body weight could be attributed to Spirulina higher content of some macro and micronutrients including high quality protein, iron, gamma-linolenic fatty acid, carotenoids, vitamins B1 and B2, $\beta$-carotene, $\alpha$-tocopherol and phycocyanin. The phycocyanin has been considered the predominant compound in the antioxidant activity of the Spirulina (Wang et al., 2007). The beneficial effect of antioxidant administration against lead acetate poisoning with respect to body weight observed in the present study confirms previous results obtained by El-Tantawy (2016) who concluded that feeding rats with antioxidants could play an important role as a prophylactic against the toxic effects of lead acetate. Lactic Acid Bacteria (LAB) are the basic in dairy fermented products such as yoghurt and kareish cheese. In recent, $\mathrm{LAB}$ has drawn attention for their efficiency to secrete extra cellular-polysaccharides (EPS) (Abou Ayana and Ibrahim, 2015).

Wang et al. (2007) reported that the relative organs weight were significantly increased after induced with lead acetate compared to negative control Meanwhile, treatment with karish, Spirulina on their mixture resulted in significant in control then negative control and decrease than positive control increasing liver and kidney. The increase in organ weight could be attributed to the relationship between organ weight increase and various toxicological effects or to the reduction in body weight gain of experimental animals. 
Table (3): Effect of kareish cheese and Spirilina plantesis on the body weight gain and organs in experimental female rats induced with lead acetate

\begin{tabular}{|c|c|c|c|c|c|}
\hline Treatments & $\begin{array}{c}\text { Initial } \\
(\mathrm{g})\end{array}$ & $\begin{array}{l}\text { Final } \\
\text { (g) }\end{array}$ & $\begin{array}{c}\text { Weight gain } \\
(\%)\end{array}$ & $\begin{array}{l}\text { Liver } \\
(\%)\end{array}$ & $\begin{array}{c}\text { Kidney } \\
(\%)\end{array}$ \\
\hline G1 & $143.3^{\mathrm{a}} \pm 1.73$ & $197.7^{\mathrm{a}} \pm 1.54$ & $37.96^{\mathrm{a}} \pm 0.19$ & $3.23^{\mathrm{c}} \pm 0.13$ & $0.54^{\mathrm{c}} \pm 0.02$ \\
\hline G2 & $143.5^{\mathrm{a}} \pm 2.88$ & $164.3^{\mathrm{e}} \pm 2.45$ & $14.49^{\mathrm{e}} \pm 0.30$ & $4.68^{\mathrm{a}} \pm 0.01$ & $0.94^{\mathrm{a}} \pm 0.01$ \\
\hline G3 & $143.5^{\mathrm{a}} \pm 1.15$ & $185.5^{\mathrm{d}} \pm 1.44$ & $29.26^{\mathrm{d}} \pm 0.28$ & $3.58^{\mathrm{b}} \pm 0.21$ & $0.61^{\mathrm{b}} \pm 0.04$ \\
\hline G4 & $143.7^{\mathrm{a}} \pm 3.46$ & $189.4^{\mathrm{c}} \pm 2.54$ & $31.80^{\mathrm{c}} \pm 0.92$ & $3.53^{b} \pm 0.24$ & $0.60^{\mathrm{b}} \pm 0.04$ \\
\hline G5 & $144.0^{\mathrm{a}} \pm 2.30$ & $191.7^{\mathrm{b}} \pm 0.95$ & $33.12^{\mathrm{b}} \pm 1.35$ & $3.47^{\mathrm{b}} \pm 0.27$ & $0.59^{b} \pm 0.02$ \\
\hline
\end{tabular}

- Means, within the same column, followed by the same letter are not significantly different at $\mathrm{P}<0.05$.

- Means are followed by the corresponding standard errors.

\section{Effect of kareish cheese, Spirluina plantesis and their mixtures on liver and kidney functions in experimental female rats induced with lead acetate}

Administration of lead acetate resulted in significant adverse effects on the liver functions of the rats, which is evidenced by a significant increase elevation (194.71, 211.35 and $339.79 \%$, respectively) in the actions of ALT, AST and ALP enzymes in G2 compared to (G1) treatment of lead acetate rats with kareish cheese, Spirulina plantesis and their mixtures exhibited improvement in the actions of ALT, AST and ALP enzymes compared to positive control rats of G2. On the other hand, there were non-significant differences in the actions of ALT, AST and ALP enzymes among rats feed on kareish cheese, Spurilina plantesis and their mixtures groups throughout the feeding periods (60 days). It was clear from Table (4) that lead acetate treatment resulted significant adverse effects on the kidney functions of the rats, which is evidenced by a significant increase elevation (221.15 and $244.12 \%$, respectively) in creatinine and urea in G2 compared to G1. Treatment of lead acetate rats with kareish cheese, Spurilina plantesis and their mixtures exhibited improvement in kidney functions compared to rats of (G2). Meanwhile, there were non-significant differences in creatinine and urea among rats fed kareich cheese, Spirulina plantesis and their mixtures throughout the feeding periods (60 days). The liver is considered one of the target organs affected by lead toxicity owing to its storage in the liver after lead exposure. Also, the liver being one of the major organs involved in the storage, biotransformation and detoxification of toxic substances, is of interest in heavy metal poisoning (El-Tantawy, 2016).
In the present study, there was a significant increase of ALT, AST and ALP activities in lead treated group as compared to the control group. These results showed that the exposure of lead affects hepatic tissue. It is believed that the most accepted hypothesis of hepatotoxicity for $\mathrm{Pb}$ is the bioactivation of $\mathrm{Pb}$ molecules to the toxic free radical by coenzymes of cytochrome $\mathrm{P} 450$ (Singh et al., 2011). When $\mathrm{Pb}$ is formed, it leads to lipid peroxidation of the polyunsaturated fatty acid in cell membranes, break down of membrane - structure and leading to the release of microsomal corboxyal esterase and other enzymes, such as amino transferases into the extra cellular compartments including serum (Bhattacharjee, 2014). The mechanism of elevated serum levels of creatinine and urea were explained by Ghorbe et al. (2001) who reported that the elevation in serum creatinine caused by lead and suggest that renal function impairment which might result from intrinsic renal lesions, decreased perfusion of the kidney obstruction of lower urinary tract or due to metabolic process caused by this metal. Rats treated with lead had significantly increase in serum urea, which has been reported to increase in acute and chronic intrinsic renal disease and also when there is decreased effective circulating blood volume with decreased renal perfusion. Treatment of kareish cheese, Spirulina plantesis and their mixture exhibited improvement in liver and kidney functions compared to G2. These results may attribute to the presence of antioxidants of Spirulina plantesis which had important beneficial effects on the liver regeneration. In this respect, it could be suggested prolonged time for more important it liver and kidney functions. 
Table (4): Effect of kareish cheese and Spirulina plantesis on the liver and kidney functions in experimental female rats induced with lead acetate

\begin{tabular}{cccccc}
\hline & \multicolumn{3}{c}{ Liver functions } & & Kidney functions \\
\cline { 2 - 6 } Treatments & $\begin{array}{c}\text { ALT } \\
(\mathbf{U} / \mathbf{L})\end{array}$ & $\begin{array}{c}\text { AST } \\
(\mathbf{U} / \mathbf{L})\end{array}$ & $\begin{array}{c}\text { ALP } \\
(\mathbf{U} / \mathbf{L})\end{array}$ & $\begin{array}{c}\text { Creatinine } \\
(\mathbf{m g} / \mathbf{d L})\end{array}$ & $\begin{array}{c}\text { Urea } \\
(\mathbf{m g} / \mathbf{d L})\end{array}$ \\
\hline G1 & $24.19^{\mathrm{c}} \pm 1.26$ & $28.80^{\mathrm{c}} \pm 2.19$ & $67.35^{\mathrm{c}} \pm 1.35$ & $0.52^{\mathrm{c}} \pm 0.02$ & $21.60^{\mathrm{c}} \pm 0.92$ \\
G2 & $71.29^{\mathrm{a}} \pm 0.74$ & $89.67^{\mathrm{a}} \pm 2.69$ & $296.2^{\mathrm{a}} \pm 3.58$ & $1.67^{\mathrm{a}} \pm 0.04$ & $74.33^{\mathrm{a}} \pm 2.20$ \\
G3 & $37.20^{\mathrm{b}} \pm 1.10$ & $58.16^{\mathrm{b}} \pm 1.82$ & $152.5^{\mathrm{b}} \pm 1.42$ & $0.95^{\mathrm{b}} \pm 0.02$ & $44.55^{\mathrm{b}} \pm 2.05$ \\
G4 & $37.75^{\mathrm{b}} \pm 1.58$ & $57.81^{\mathrm{b}} \pm 2.20$ & $151.5^{\mathrm{b}} \pm 0.86$ & $0.93^{\mathrm{b}} \pm 0.04$ & $43.89^{\mathrm{b}} \pm 2.24$ \\
& $36.82^{\mathrm{b}} \pm 1.05$ & $57.56^{\mathrm{b}} \pm 1.47$ & $150.2^{\mathrm{b}} \pm 3.02$ & $0.90^{\mathrm{b}} \pm 0.02$ & $43.18^{\mathrm{b}} \pm 1.25$ \\
\hline
\end{tabular}

- Means, within the same column, followed by the same letter are not significantly different at $\mathrm{P}<0.05$.

- Means are followed by the corresponding standard errors

Effect of kareish cheese and Spurilina plantesis on serum MDA and erythrocyte (SOD, Catalase, GSPx and GSH) levels in experimental female rats induced with lead acetate

Table (5) showed the activity levels of serum, enzymatic antioxidants \%, SOD, Catalase, GSH-Px and non-enzymatic antioxidant, GSH in erythrocyte, and malonaldehyde content respectively, in normal and experimental rat groups. The amount of serum maloaldehyde (MDA) was significantly increased by about $145.36 \%$ in G2 compared to (G1). While the activities of enzymatic antioxidants (SOD, Catalase, GSH-Px) and non-enzymatic antioxidant (GSH reduced) were significantly decreased (38.50, and 31.78 , 53.04 and $44.96 \%$, respectively) in rats induced with lead acetate $(\mathrm{G} 2)$, when compared with the normal group G1. Treatment the experimental lead acetate rat groups with kareish cheese, Spirulina plantesis and their mixtures decreased the levels of malonaldehyde (MDA) and increased the activities of enzymatic antioxidant, (SOD, Catalase, GSH-Px) and non-enzymatic antioxidant, GSH reduced level. Hepatic induced by lead acetate was associated with oxidative stress due to lead acetate induced free radical production and toxic (Atef et al., 2013). Oxidative stress plays an important role in chronic complications of lead acetate and is postulated to be associated with increasing lipid peroxidation. The cytotoxic action of lead acetate is associated with the generation of reactive oxygen species causing oxidative damage. The increased free radicals produced may react with polyunsaturated fatty acids in cell membranes leading to lipid peroxidation. Lipid peroxide-mediated damage has been observed in the development of lead acetate. The increased lipid peroxidation in the serum with lead acetate may be due to the observed remarkable increase in the concentration of free radical in the serum induced with lead acetate G2.

Table (5): Effect of kareich cheese and Spirulina plantesis on serum MDA and Erythrocyte SOD, Catalase, GSPx and GSH) levels in experimental rats female induced with lead acetate

\begin{tabular}{cccccc}
\hline Treatments & $\begin{array}{c}\text { SOD } \\
(\mathbf{U} / \mathbf{m l})\end{array}$ & $\begin{array}{c}\text { Catalase } \\
(\mathbf{U} / \mathbf{m l})\end{array}$ & $\begin{array}{c}\text { GSPx } \\
(\mathbf{U} / \mathbf{m l})\end{array}$ & $\begin{array}{c}\text { GSH } \\
(\mathbf{m g} / \mathbf{d l})\end{array}$ & $\begin{array}{c}\text { MDA } \\
(\mathbf{n m o l} / \mathbf{m l})\end{array}$ \\
\hline G1 & $306.2^{\mathrm{a}} \pm 3.562$ & $140.23^{\mathrm{a}} \pm 1.287$ & $171.30^{\mathrm{a}} \pm 0.751$ & $40.28^{\mathrm{a}} \pm 0.739$ & $11.64^{\mathrm{c}} \pm 0.370$ \\
$\mathbf{G 2}$ & $188.3^{\mathrm{c}} \pm 1.299$ & $95.66^{\mathrm{c}} \pm 3.268$ & $80.45^{\mathrm{c}} \pm 3.724$ & $22.17^{\mathrm{c}} \pm 1.253$ & $28.56^{\mathrm{a}} \pm 2.055$ \\
$\mathbf{G 3}$ & $276.1^{\mathrm{b}} \pm 2.973$ & $131.6^{\mathrm{b}} \pm 2.023$ & $146.90^{\mathrm{b}} \pm 1.097$ & $32.86^{\mathrm{b}} \pm 3.961$ & $19.44^{\mathrm{b}} \pm 1.986$ \\
$\mathbf{G 4}$ & $276.4^{\mathrm{b}} \pm 4.272$ & $132.19^{\mathrm{b}} \pm 1.264$ & $147.36^{\mathrm{b}} \pm 0.785$ & $32.78^{\mathrm{b}} \pm 2.182$ & $20.17^{\mathrm{b}} \pm 0.675$ \\
& & & & & \\
G5 & $278.4^{\mathrm{b}} \pm 1.940$ & $133.57^{\mathrm{b}} \pm 2.061$ & $148.15^{\mathrm{b}} \pm 1.241$ & $35.60^{\mathrm{b}} \pm 2.656$ & $18.48^{\mathrm{b}} \pm 1.432$ \\
\hline
\end{tabular}

\footnotetext{
- Means, within the same column, followed by the same letter are not significantly different at $\mathrm{P}<0.05$.
}

- Means are followed by the corresponding standard errors. 
In the current study, level of serum MDA in groups treated with kareish cheese and Spirulina plantesis showed a significant reduction which indicates a decrease rate of lipid peroxidation (Supratim et al., 2007). In general, superoxide dismutase (SOD) is an important antioxidant enzyme which catalyzes the conversion of toxic superoxide radical to less reactive hydrogen peroxide (Taro and Hirotaka, 2017). The SOD is known to be reduced markedly in lead acetate induced hepatic. While oxidative stress could be ameliorated via the elevation of hepatic SOD level (Ismail et al., 2012). In addition, glutathione peroxidase (GPx) is another antioxidant enzyme commonly used to investigate the oxidative stress. It has been indicated that antioxidant-like compounds produce hepatic protection through an increase in GPx to scavenge the free radicals (Zuhal et al., 2011).

Effect of kareich cheese and Spirulina plantesis on lead level in liver and kidney of experimental female rats induced with lead acetate

Administration of lead acetate produced significant adverse effects on the lead level in liver and kidney of the rats, which is evidenced by a significant increase elevation (444 and $105.13 \%$, respectively) in liver and kidney of G2 compared to G1. Treatment of lead acetate rats with kareich cheese; Spirulina plantesis and their mixtures exhibited improvement lead level in liver and kidney compared to G2. On the other hand, there were non-significant variances in the lead level in liver and kidney among rats feed on kareich cheese, Spurilina plantesis and their mixtures groups throughout the feeding periods (Table 6). These results proved that lead induced hepatic toxicity via increased oxidative stress on hepatocytes with subsequent development of degenerative hepatocellular changes and activation of pro apoptotic genes with subsequent induction of apoptosis, and these results was confirmed by the increased lead content in liver tissue of lead treated groups (Jarrar and Taib, 2012).

Table (6): Effect of fed on Kareich cheese and Spirulina platensis on Lead level in liver and kidney of experimental female rats induced with lead acetate

\begin{tabular}{ccc}
\hline Treatments & Liver $(\mathbf{m g} / \mathbf{1 0 0 g}$ & Kidneys ( mg/100g \\
\hline G1 & $2.50^{\mathrm{a}} \pm 0.08$ & $1.56^{\mathrm{b}} \pm 0.32$ \\
G2 & $13.60^{\mathrm{a}} \pm 2.07$ & $3.20^{\mathrm{b}} \pm 0.28$ \\
$\mathbf{G 3}$ & $7.54^{\mathrm{a}} \pm 0.31$ & $2.93^{\mathrm{b}} \pm 0.07$ \\
$\mathbf{G 4}$ & $6.35^{\mathrm{a}} \pm 0.77$ & $2.88^{\mathrm{b}} \pm 0.04$ \\
G5 & $5.55^{\mathrm{a}} \pm 0.89$ & $2.60^{\mathrm{b}} \pm 0.34$
\end{tabular}

- Means, within the same column, followed by the same letter are not significantly different at $\mathrm{P}<0.05$.

- Means are followed by the corresponding standard errors

\section{CONCLUSION}

From the present study, it can be concluded that the feed with Kareish cheese and Spirulina platensis protect liver and Kidney tissues from damage with lead acetate by decrease the level of lipid peroxidation and increase antioxidant activities, which need a long period of treatments.

\section{REFERENCES}

Abou Ayana, I. A. and A. E. Ibrahim (2015). Attributes of low-fat yogurt and kareish cheese made using polysaccharides Producing lactic acid bacteria. American Journal of Food Technology, 10: 48-57.

Aebi, H. (1984). Catalase in vitro. Methods Enzymol., 105: 121-136.

AOAC (1981). Official method of analysis of the association of official analytical chemists. Published by the Association of Official Analytical Chemists, Inc., Arlington, USA.

AOAC (2000). Official methods of analysis of the association of official analytical chemists. $\left(17^{\text {th }}\right.$ ed.). Vol. II. Arlington, VA: Association of Official Analytical Chemists.

Attia, A. M. M., F. A. A. Ibrahim, Gh. M. Nabil and S. W. Aziz (2013). Antioxidant effects of ginger (Zingiber officinale Roscoe) against lead acetate-induced hepatotoxicity in rats. African Journal of Pharmacy and Pharmacology, 7(20): 1213-1219.

Barltrop, D. and H. Khoo (1975). The influence of nutritional factors on lead absorption, Postgraduate Medical Journal, November, 51: 795-800.

Bergmeyer, H. U. and M. Harder (1986). A colorimeteric method of determination of serum glutamic oxaloacetic and glutamic pyruvic transaminase. Clin. Biochem., 24: 2834.

Bhattacharjee, S. (2014). Membrane lipid peroxidation and its conflict of interest: the two faces of oxidative stress. Current Sci., 107(11): 18111823.

Djebli, N., M. Slimani and A. Aoues (2004). Effect of lead exposure on dopaminergic transmission in the rat brain. Toxicol., 207: 363-368.

Ellman, G.L. (1959). Tissue sulfhydrl groups. Archives of Biochem. and Biophys., 82: 70-77.

El-Neweshy, M. S. and Y. S. El-Sayed (2011). Influence of vitamin $\mathrm{C}$ supplementation on lead-induced histopathological alterations in male rats. Experimental and Toxicologic Pathology, 63: 221-227.

El-Sokkary, G. H., G. H. Abdel-Rahman and E. S. Kamel (2005). Melatonin protects against leadinduced hepatic and renal toxicity in male rats. Toxicology, 213: 25.

El-Tantawy, W. H. (2016). Antioxidant effects of Spirulina supplement against lead acetateinduced hepatic injury in rats. Journal of Traditional and Complementary Medicine, vol. 6: 327-331. 
Fawcett, J. K. and J. E. Scott (1960). Enzymatic colorimetric method for determination urea in serum, plasma and urine. J. Clin. Path., 13: 156-162.

Ghorbe, F., M. Boujelbene, F. Makni-Ayadi, F. Guermazi, A. Kammoun, J. Murat, F. Croute, J. P. Soleilhavoup and A. E. Feki (2001). Effect of Chronic Lead Exposure on Kidney Function in Male and Female Rats: Determination of a Lead Exposure Biomarker; Physiology and Biochem., 5(109): 457-463, 467.

Hassan, N. S. Y., Z. M. Mohamed and A. B. El-Sayed (2015). Production and Evaluation of Pasta Supplemented with Spirulina platensis Biomass. Advances in Food Sciences, 37(4):153-162.

Hemalatha, K., K. Pugazhendy, K. Jayachandran, C. Jayanthi and M. Meenamba (2012). Studies on the protective efficacy of Spirulina against lead acetate induced hepatotoxicity in Rattus norvegicus. International Journal of Chemical and Analytical Science, 3(8): 1509-1512.

Henry, R. J. (1974). Clinical Chemistry, Principles and Techniques, $2^{\text {nd }}$ Edition, Harper and Raw, p. 525.

Ibrahim, N. M., E. A. Eweis, H. S. El-Beltagi and Y. E. Abdel-Mobdy (2012). Effect of lead acetate toxicity on experimental male albino rat. Asian Pac. J. Trop. Biomed., 2: 41-46.

Ismail, N. A., S. Okasha, A. Dhawan, A. Rahman, N. Hamid and O. Shaker (2012). Glutathione peroxidase. Superoxide dismutase and catalase activities in children with chronic hepatitis. Advances in Bioscience and Biotechnology, 3: 972-977.

Jarrar, B. M. and N. T. Taib (2012). Histological and histochemical alteration in the liver induced by lead chronic toxicity .Saudi Journal of Biological Sciences, 19: 203-210.

Kadhim, S. H., A. A. Nazarmuteb, Z. kreem and M. M. Ubaid (2016). The effect of penicillamine in reducing the toxic effects of lead acetate on some blood parameters, liver functions and testicular tissue in male rats. Ijppr. Human, 5(3): 22-40.

Kostial, K. Maljkovic and S. I.andJugo (1974). Lead absorption from the intestine in newborn rats. Arch Toxic., 3: 265.

Lalith Kumar, V. and Muralidhara (2014). Ameliorative effects of ferulic acid against lead acetateinduced oxidative stress, mitochondrial dysfunctions and toxicity in prepubertal rat brain. Neurochem. Res., 39: 2501-2515. http://dx.doi.org/10.1007/s11064-014-1451-7

Meltzer, H. M., M. Folmer, S. Wang, Q. Lie, A. Maage and H. H. Mundal (1997). Supplementary selenium influences the response to fatty acid induced oxidative stress in humans. Biological Trace Element Research, 60: 51-67.

Nishikimi, M., N. A. Roa and K. Yog (1972). The occurrence of superoxide anion in the reaction of reduced phenazine methosulphate and molecular oxygen. Biochemist. Res. Common., 46: 849-854.

Rahman, M. A., N. F. Moitry, M. Alam, Z. Yasmin, D. Debnath and M. Mostofa (2012). Effects of Spirulina in lead induced toxicities in long evans rats. J. Environ. Sci. and Natural Resources, 5(1): 79-82.

Reeves, P. G., F. Nielen, G. C. Hand Fahey (1993). AIN-93 purified diets for laboratory rodents: final report of the American Institute of Nutrition ADHOC writing Committee on the formulation of the AIN-76a rodent diet. J. Nutr., 123(12): 1939-1951.

Rotruck. J. J., A. L. Pope, H. E. Ganther and A. B. Swanson (1973). Selenium: biochemical role as a component of glutathione peroxidase. Science, 179: 588-590.

Sharma, A., L. Sharma and M. Kansal (2010). The effect of oral administration of Allium sativum extracts on lead nitrate induced toxicity in male mice, Food Chem. Toxicol., 48:928-936.

Silbergeld, E. K. and H. S. Adler (1978). Diet and lead toxicity. Proc. Nutr. Soc. Vol., 38: 243-250.

Singh, A., K. Tej Bhat and P. S. Om (2011). Clinical Biochemistry of Hepatotoxicity. Journal of Clinical Toxicology, S: 4.

Snedecor, G. W. and W. G. Cochran (1980). Statistical methods. University press, Amens, lowe.

Supratim, R., R. Kunal and S. Chandana (2007). Exploring the Protective effect of ascorbic acid and aqueous extract of Spirulina platensis on methotrexate-Induced lipid peroxidation. Iranian Journal of Pharmaceutical Sciences Autumn, 3(4): 217-228.

Taro, S. and I. Hirotaka (2017). Hydrogen peroxide produced by superoxide dismutase SOD-2 activates sperm in Caenorhabditis elegans. J. Biol. chem., 292: 14804-14813.

Todaro, A, F. A. Adly and O. A. Omar (2013). History, Processing and Quality Enhancement of Traditional Egyptian Kariesh Cheese: A Review. Food Science and Technology, 1(1): $1-6$.

Varley, H., A. Gewenlock and M. Bell (1980). Practical clinical Biochemistry. vol. 1. $5^{\text {th }}$ ed., pp. 741, 897. London: William Heinemen Medical. Books, Ltd.

Wang L, B. Pan, J. Sheng and Q. Hu XuJ (2007). Antioxidant activity of Spirulina platensis extracts by supercritical carbon dioxide extraction. Food Chem., 105: 36-41.

Yuan, G., S. Dai, Z. Yin, H. Lu and R. Jia (2014). Subchronic lead and cadmium co-induce apoptosis protein expression in liver and kidney of rats. Int. J. Clin. Exp Pathol, 7(6): 2905-2914.

Zuhal, Y. I., I. U. Nil and Y. Filiz (2011). The role of oxidative stress and antioxidants in the pathogenesis of age-related macular degeneration. Clinical Science, 66(5): 743-746. 


\section{تأثير التغذية بطحلب Spurlina platensis والجبنة القريش على أضرار الكبا والكلى الناجمة عن سمية الرصاص في القئران

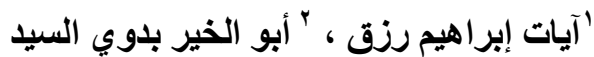

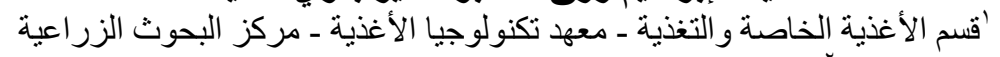

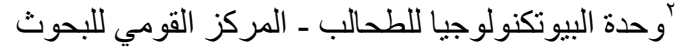

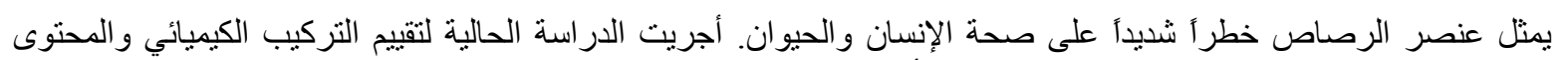

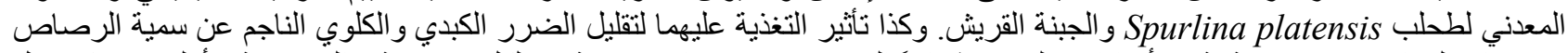

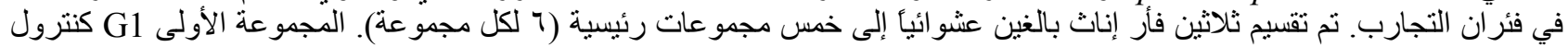

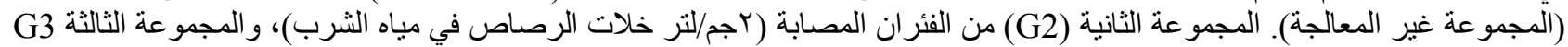

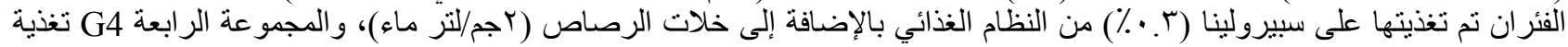

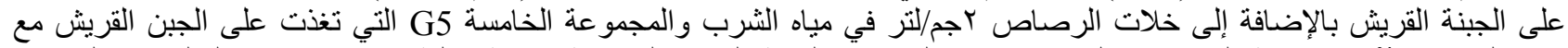

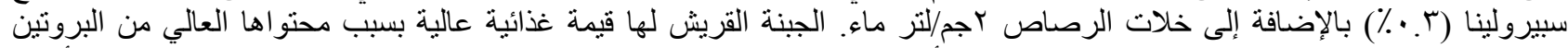

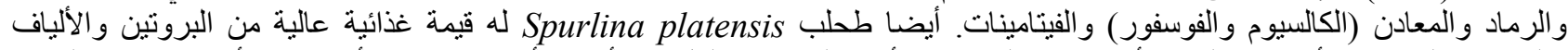

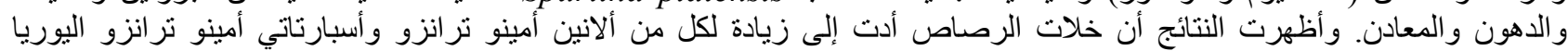

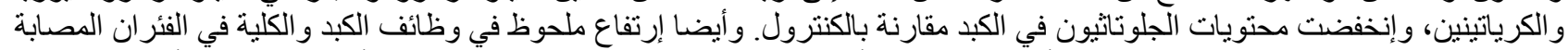

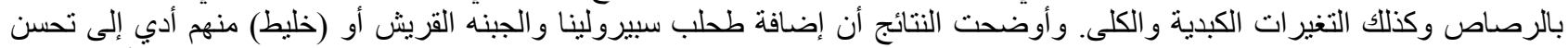

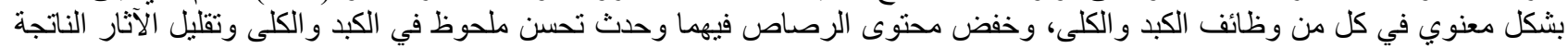

